\title{
O JUIZ E A DÚVIDA: REFLEXÕES SOBRE A DECISÃO JUDICIAL ${ }^{1}$
}

\section{THE JUDGE AND THE DOUBT: REFLECTIONS ABOUT THE JUDICIAL DECISION}

\section{Renê Hellman}

Mestre em Ciência Jurídica (UENP). Professor do Departamento de Direito Processual da UEPG. Coordenador do Grupo de Pesquisa Observatório Processual do STJ na UEPG. Doutorando em Direito pela UFPR. Membro do IBDP e da ABDPRO. Ponta Grossa /PR. Email: renehellman@hotmail.com

\section{Eduardo Galduróz}

Juiz de Direito (Tribunal de Justiça do Estado de São Paulo). Secretário do Conselho Executivo da Associação dos Juízes para a democracia - biênio 2015-2017. Ibiúna /SP.

RESUMO: Este artigo tem a finalidade de defender a necessidade de exposição das dúvidas do juiz a respeito do objeto do conflito processual na decisão judicial. Trata-se de um direito das partes, que decorre do dever de fundamentação das decisões judiciais, da garantia do contraditório e do dever de boa-fé que se impõe também ao juiz. Defende-se a necessidade de exposição da dúvida na decisão judicial, para possibilitar a construção de decisões mais honestas, livrando o juiz do peso de sempre ter certeza sobre o que está julgando, o que otimizará os mecanismos de controle da decisão pelas partes e de reinterpretação da decisão por outros julgadores no mesmo processo. O método utilizado foi o dedutivo e a pesquisa desenvolveu-se a partir da leitura e interpretação de obras doutrinárias e de textos normativos.

PALAVRAS-CHAVE: decisão judicial; cognição; fundamentação; certeza; dúvida.

\footnotetext{
${ }^{1}$ Artigo recebido em 80/09/2021 e aprovado em 16/11/2021.
} 


\begin{abstract}
In this article, we stand up for the necessity that a judge points out any doubt he may have about the object of adjudication. We consider this as a parties' right, which comes from a legal duty of exposing all the fundaments of judicial decisions, the guarantee that a party can have the opportunity to contradict the opposing arguments and the duty of good faith that is imposed not only to the parties but also to judges. This will allow the construction of more honest decisions freeing the judge of the weight to always be sure about what he is judging, what leads to the enhancement of decision control mechanisms by the parties and the reinterpretation of the next adjudicators in that procedure. Deductive method was used, and the research was developed based on reading and interpretation of doctrinal works and normative texts.
\end{abstract}

KEYWORDS: judicial decision; adjudication; cognition; necessity of fundaments; certainty; doubt.

\title{
1. INTRODUÇÃO
}

A decisão judicial é tema que toca diretamente no princípio democrático, porque é a partir dela que o Poder Judiciário exerce o seu poder jurisdicional e é controlado nesse exercício pelas partes e pela sociedade. Por conta disso, importa sempre debater sobre a construção da decisão judicial, pois isso implica no debate sobre as formas de controle do exercício do poder jurisdicional.

Espera-se que o processo judicial resulte na tomada de uma decisão que julgue adequadamente o caso conflituoso, dando a ele uma solução que se enquadre nos limites do ordenamento jurídico. Espera-se, ainda, que o juiz ao julgar tenha convicção sobre o que está decidindo, que é produto das certezas construídas a partir do debate entre as partes e da instrução processual.

Há casos, entretanto, em que o juiz chega no momento processual da decisão sem que tenha formado certezas a respeito do objeto do julgamento e mesmo assim seja compelido a decidir. Esse estado mental de dúvida não poderá ser mascarado pelo juiz na fundamentação da decisão judicial. 
Para demonstrar isso, este artigo está dividido em três partes. Na primeira, serão analisadas as normas fundamentais do processo que impactam mais diretamente no procedimento decisório. Na segunda parte, a análise será centrada na cognição judicial e na esperança de certeza sobre os fatos da causa que ela gera. Por fim, na terceira parte defenderse-á a necessidade de exposição da dúvida na decisão judicial, para possibilitar a construção de decisões mais honestas, livrando o juiz do peso de sempre ter certeza sobre o que está julgando, o que possibilitará a otimização dos mecanismos de controle da decisão pelas partes e de reinterpretação da decisão por outros julgadores no mesmo processo.

O método utilizado foi o dedutivo e a pesquisa desenvolveu-se a partir da leitura e interpretação de obras doutrinárias e de textos normativos.

\section{AS NORMAS FUNDAMENTAIS DO PROCESSO CIVIL E O PROCEDIMENTO DECISÓRIO}

O processo é regido por uma série de normas que derivam de uma norma em especial: o devido processo legal, previsto na Constituição Federal, em seu art. $5^{\circ}$, LIV. A garantia do devido processo legal assegura ao jurisdicionado que qualquer intervenção ordenada pelo Poder Judiciário no âmbito da sua individualidade deva ser em atenção às regras do jogo, o que gera segurança jurídica e previsibilidade e, mais do que isso, preserva a liberdade.

Nessa linha, Eduardo José da Fonseca Costa ${ }^{2}$ destaca que "processo garante à parte a liberdade [FREEDOM] de decidir pelo que entende e pelo que lhe convém no processo" e, como consequência disso, essa garantia contrajurisdicional que é o processo implica em uma divisão equilibrada de papéis entre o juiz e as partes: "o juiz não arvora a si as liberdades da parte, nem lhes controla o exercício; por sua vez, a parte não se arvora nos poderes do juiz, conquanto lhes controle o exercício".

Esta premissa normativa é fundamental para a compreensão dos comandos outros que decorrem da ideia de devido processo legal. Não se vai aqui analisar todas as normas fundamentais do Processo Civil, apenas aquelas que têm impacto imediato no procedimento decisório.

\footnotetext{
${ }^{2}$ COSTA, Eduardo José da Fonseca. Processo: garantia de liberdade (freedom) e garantia de "liberdade" (liberty). Disponível em: <https://emporiododireito.com.br/leitura/processo-garantia-de-liberdade-freedom-egarantia-de-liberdade-liberty>. Acessado em 09/08/2020.
} 
Desse modo, partindo-se do devido processo legal, é fundamental que se analise o contraditório, a imparcialidade, a fundamentação das decisões judiciais, a boa-fé processual e aquilo que parcela da doutrina convencionou chamar de "dever de cooperação".

O disposto no art. 9\% $\mathrm{CPC}$ encerra a ideia de contraditório prévio como a regra geral a reger o Processo Civil brasileiro, impondo ao magistrado o dever de promover a informação às partes sobre o que ocorre no processo e a bilateralidade de audiência, ou seja, oportunizar que elas falem nos autos sempre antes de ser proferido qualquer ato decisório. A essa dimensão do contraditório se convencionou chamar de contraditório formal.

É da essência do processo no Estado Democrático de Direito a regência pelo contraditório, até mesmo porque este direito está previsto na $\mathrm{CF} / 88$, art. $5^{\circ}, \mathrm{LV}$, na qualidade de fundamental, sendo uma das manifestações, ao lado da ampla defesa, do devido processo legal.

O art. 10/CPC oferece uma visão substancial do contraditório: o direito de influência e a garantia de não-surpresa. Isso significa que não basta informar as partes sobre o que ocorre no processo e permitir que elas se manifestem, é necessário que o juiz se deixe influenciar por aquelas manifestações.

O direito de influência que é dado às partes implica em um dever que recai sobre o magistrado de manifestar-se sobre os argumentos trazidos por aquelas ao processo, mesmo quando sua decisão é no sentido de rejeitá-los. Na realidade, é extremamente importante a análise dos argumentos rejeitados, de maneira que as partes possam controlar a atividade jurisdicional. E aqui se nota uma clara vinculação entre o contraditório e a fundamentação das decisões judiciais.

Além disso, a vedação à decisão surpresa implica no dever do juiz de antes de decidir com base em algum fundamento que não tenha sido levado anteriormente ao processo, converter o julgamento em diligência e oportunizar que as partes falem sobre ele, mesmo naqueles casos de matéria de ordem pública, sobre a qual o juiz possa decidir de ofício.

E aqui não importa se se trata de fundamento fático ou jurídico. $\mathrm{O}$ dispositivo legal refere-se genericamente a fundamento, do que se conclui, já que se trata de regulação de direito fundamental, que a adequada interpretação a ser dada é aquela que potencializa e não a que restringe o contraditório. 
Percebe-se claramente uma ligação entre o direito ao contraditório e o dever de fundamentação das decisões judiciais. Um não pode ser plenamente compreendido sem o outro e é por essa razão que o art. 489, $\S 1 \% \mathrm{CPC}$, quando trata da fundamentação analítica das decisões judiciais, ao mesmo tempo em que especifica o dever fundamental previsto no art. 93, IX/CF, também confere normatividade à garantia fundamental do art. 5, $\mathrm{LV} / \mathrm{CF}$.

A fundamentação, como se sabe, tem dupla função: uma interna e outra externa. Expor, o juiz, os motivos do seu convencimento, o que significa possibilitar que as partes saibam qual foi o caminho percorrido por ele na compreensão e interpretação dos fatos da causa, das provas e do direito aplicado ao caso. Com isso, as partes têm condições de fazer o controle da qualidade formal e substancial da decisão. Por outro lado, essa exposição aliada à regra da publicidade do processo, permite que a sociedade em geral possa conhecer como decidem os magistrados e, pelos meios democráticos, fazer críticas à atividade jurisdicional.

Fundamentar a decisão é descortinar o palco onde se dá o processo interpretativo do caso conflituoso e, por isso, é condição de possibilidade para um processo judicial democrático.

O juiz que preside o processo e decide o conflito, além de todos os demais limites a que está submetido, também deve ser imparcial. Rosemiro Pereira Leal entende que a imparcialidade do juiz não é um princípio de direito processual e, sim, um dever constitucional do Estado-juiz e, "como direito-garantia das partes, as leis processuais cuidam da suspeição e impedimento dos juízes como vícios insuperáveis e causadores da nulidade dos atos jurisdicionais"3.

As regras de impedimento e de suspeição previstas nos arts. 144 e 145/CPC servem para garantir às partes que não irá atuar no processo aquele juiz que possa ter algum interesse no objeto da causa ou alguma ligação com os sujeitos da demanda. $\mathrm{O}$ juiz distanciado do conflito é o que se imagina ser o mais capaz de interpretar as afirmações de fato, as provas e os textos normativos de forma adequada e proferir a decisão mais acertada possível.

A boa-fé processual prevista no $\mathrm{CPC} / 2015$, em seu art. $5^{\circ}$, é exigida como comportamento de todos aqueles que participem do processo. Ao referir-se ao comportamento de boa-fé, o legislador regulamentou a chamada boa-fé objetiva. Avalia-se,

\footnotetext{
${ }^{3}$ LEAL, Rosemiro Pereira. Teoria geral do Processo: primeiros estudos. $14^{\mathrm{a}}$ ed. rev. ampl. e atual. Belo Horizonte: Fórum, 2018, p. 180.
} 
de forma objetiva, sem verificação da intenção do agente, a conduta praticada e se ela viola a expectativa gerada nos demais participantes daquela relação. Não se trata mais "de recorrer à boa-fé apenas no plano subjetivo, para justificar ou sancionar o erro acerca da realidade fático-jurídica" ${ }^{4}$. O dever de probidade processual é decorrência lógica da ideia de que o processo judicial não tem o condão de servir de instrumento para o cometimento de ilegalidades, ao contrário. Assim, muito embora haja disputa entre as partes em relação aos direitos objetos da demanda, há determinados deveres a serem observados, eis que fincados em uma preocupação de fundo ético ${ }^{5}$.

Daí porque este imperativo de probidade processual deve ser visto não apenas como uma obrigação imposta às partes, mas também - se não sobretudo - à atuação do magistrado, que, extraindo sua legitimidade democrática justamente da fundamentação de suas decisões, tem a obrigação de dar a conhecer os bastidores de seu processo decisório, é dizer, o raciocínio por meio do qual analisou e resolveu as questões submetidas a sua análise.

Trata-se do dever de honestidade intelectual, que, embora não expressamente catalogado pelo ordenamento jurídico, consubstancia faceta indissociável do primado da boa-fé objetiva a que se refere, por exemplo, o artigo 489, $\S 3^{\circ}$, do CPC: é uma impossibilidade lógica exigir que a decisão seja interpretada de acordo com o princípio da boa-fé sem que este postulado tenha sido antes observado, em necessária premissa, por seu próprio prolator.

Por fim, sem a intenção de esgotar a temática das normas fundamentais do Processo, mas, sim, introduzir rapidamente aquelas que tenham ligação mais próxima com o procedimento de tomada da decisão, é importante tratar do chamado dever de cooperação processual.

$\mathrm{O}$ art. $6 \% \mathrm{CPC}$ prevê que "todos os sujeitos do processo devem cooperar entre si para que se obtenha, em tempo razoável, decisão de mérito justa e efetiva".

A respeito do tema da cooperação processual, a doutrina brasileira encontra-se dividida basicamente entre aqueles que partem do pressuposto que o CPC/2015 instituiu um

\footnotetext{
${ }^{4}$ THEODORO JR., Humberto e outros. Novo CPC: fundamentos e sistematização. Rio de Janeiro: Forense, 2015, p. 171.

${ }^{5}$ MARINONI, Luiz Guilherme, MITIDIERO, Daniel. Código de Processo Civil comentado artigo por artigo. São Paulo: RT, 2008, p. 112.
} 
modelo cooperativo de processo e os críticos a essa ideia, que entendem não haver que se falar em um modelo processual que não aquele instituído pela $\mathrm{CF} / 88$.

Dentre os defensores da existência de um modelo cooperativo de processo destacase o professor gaúcho Daniel Mitidiero ${ }^{6}$, que elenca os pressupostos sociais, lógicos e éticos da cooperação no processo: 1) o juiz no modelo cooperativo tem por finalidade alcançar um ponto de equilíbrio, desempenhando o duplo papel de ser paritário no diálogo e assimétrico na decisão; 2) revisão crítica dos brocardos da mihi factum, dabo tibi jus e iura novit curia, pois o juiz deixa de ter como função única a valoração apenas dos fatos trazidos pelas partes, dada a superação da ideia de que haja uma distinção objetiva entre questões de fato e questões de direito. Demais disso, pode o julgador proceder à investigação de fatos que não tenham sido levados pelas partes, mas que possam influir no julgamento da causa e é das partes o direito de se pronunciarem sobre a valoração jurídica da causa, mesmo daqueles pontos que o juiz poderia conhecer de ofício, na superação da ideia de que o julgador conhece o direito, que já não pode mais ser concebido como aquele fruto apenas da criação legislativa, dada a grande influência da jurisprudência na construção dos direitos; 3) todos os participantes do processo devem agir lealmente em juízo.

A Escola Mineira de Processo usa a expressão "comparticipação" para referir-se ao disposto no $\mathrm{CPC} / 2015$, art. $6^{\circ}$, que seria uma releitura democrática da ideia de cooperação "que leva a sério o contraditório como influência e não surpresa, de modo a garantir a influência de todos na formação e satisfação das decisões e inibir aqueles atos praticados em má-fé processual"7.

A ideia de comparticipação certamente aproxima-se mais do modelo constitucional de Processo, até mesmo porque afasta a noção de que as partes devem colaborar entre si e com o juiz, colocando este como a figura central do processo: "esta utópica solidariedade processual não existe (nem nunca existiu): as partes querem ganhar e o juiz quer dar vazão à sua pesada carga de trabalho" 8 .

\footnotetext{
${ }^{6}$ MITIDIERO, Daniel. Colaboração no Processo Civil: pressupostos sociais, lógicos e éticos. $2^{\mathrm{a}}$ ed. rev. atual. e ampl. São Paulo: Editora Revista dos Tribunais, 2011.

${ }^{7}$ THEODORO JR., Humberto e outros. Novo CPC: fundamentos e sistematização. Rio de Janeiro: Forense, 2015 , p. 60.

${ }^{8}$ THEODORO JR., Humberto e outros. Novo CPC: fundamentos e sistematização. Rio de Janeiro: Forense, 2015, p. 60.
} 
Fredie Didier Jr., por sua vez, trata do que ele chama de princípio da cooperação, que seria uma construção a partir do devido processo legal, da boa-fé processual e do contraditório. O modelo de processo cooperativo para o professor baiano é caracterizado pelo redimensionamento do contraditório, que "é valorizado como instrumento indispensável ao aprimoramento da decisão judicial e não apenas como uma regra formal que deve ser observada para que a decisão seja válida"9.

A partir dessa ideia, Didier enxerga, com relação às partes, os seguintes deveres que decorrem da cooperação: a) de esclarecimento (redação clara e coerente das petições); b) de lealdade (proibição da litigância de má-fé); c) de proteção (proibição de causar danos ao adversário)..$^{10}$

Já com relação ao órgão jurisdicional, os deveres são: a) de lealdade, como decorrência da boa-fé processual que também se impõe ao juiz; b) de esclarecimento, a partir do qual o juiz busca sair do estado de dúvida em que eventualmente se encontre a respeito das alegações das partes, "para evitar decisões tomadas em percepções equivocadas ou apressadas", mas não só isso, já que a partir do dever de esclarecimento o juiz deve deixar claras as razões do seu convencimento; c) de consulta, pois não pode o magistrado decidir sem que haja manifestação das partes a respeito do tema; d) de prevenção, que se aplica em quatro áreas: "explicitação de pedidos pouco claros, o caráter lacunar da exposição dos fatos relevantes, a necessidade de adequar o pedido formulado à situação concreta e a sugestão de certa atuação pela parte". ${ }^{11}$

Não se pode esquecer, entretanto, embora a discussão aqui não seja esta, que há uma corrente doutrinária que combate a visão da cooperação como um novo modelo de processo. Nessa linha, Diego Crevelin de Sousa, em texto contundente a respeito do caráter mítico da cooperação processual, defende que os deveres que parte da doutrina afirme serem dela decorrentes, na realidade não o são, pois "só repetem manifestações de outras garantias

\footnotetext{
${ }^{9}$ DIDIER JR., Fredie. Curso de Direito Processual Civil: introdução ao Direito Processual Civil, parte geral e processo de conhecimento. $17^{\mathrm{a}}$ ed. rev. ampl. e atual. Salvador: JusPodivm, 2015, p. 125.

${ }^{10}$ DIDIER JR., Fredie. Curso de Direito Processual Civil: introdução ao Direito Processual Civil, parte geral e processo de conhecimento. $17^{\text {a }}$ ed. rev. ampl. e atual. Salvador: JusPodivm, 2015, p. 127-128.

${ }^{11}$ DIDIER JR., Fredie. Curso de Direito Processual Civil: introdução ao Direito Processual Civil, parte geral e processo de conhecimento. $17^{\mathrm{a}}$ ed. rev. ampl. e atual. Salvador: JusPodivm, 2015, p. 128-130.
} 
processuais ou institutos infraconstitucionais específicos, tornando descartável tal formulação genérica"12.

O professor capixaba desmistifica os deveres de consulta, que "manifesta o conteúdo do contraditório como proibição de decisão surpresa"; de diálogo, pois quando se fala nele, "não se está falando de um instituto autônomo, com conteúdo, regime e efeitos próprios, mas empregando um neologismo para se referir à garantia do contraditório"; de lealdade, que já está regulado em outros dispositivos e decorre especificamente do dever de comportamento de boa-fé; de prevenção, que "também alude à incidência das regras de sanação, aproveitamento e pós-eficacização de atos processuais inadmissíveis"; e, por fim, o dever de auxílio, que encerraria um paradoxo: “ou (i) é mera afetação dogmática (quiçá epistemológica, quando indica simplesmente dever funcional típico, que nada tem de auxílio) ou (ii) é grave inconstitucionalidade"13.

Afora essa discussão, que é sobremaneira importante, mas que se estabelece num campo teórico mais elevado, o fato é que essa visão "cooperativa" do processo tem servido, em larga medida, para a justificação de uma conduta mais ativa do juiz no contraditório. É comum que a doutrina defenda uma participação maior do juiz no debate processual, recusando a passividade e estimulando-o a buscar sanar suas dúvidas sobre os fatos da causa, a fim de que a decisão judicial seja mais completa, até mesmo porque se persegue no processo a chamada cognição exauriente.

O que se quer, ao fim do processo, na tomada da decisão judicial é munir o juiz de certezas a respeito do objeto da controvérsia, tanto do ponto de vista dos fatos, quanto do direito a ser aplicado. Espera-se romanticamente que o juiz, pelas provas, reste "cabalmente convencido", que seu raciocínio o conduza a um campo "indene de dúvidas", que não haja qualquer conflito interno para o juiz quando ele tiver que proferir sua decisão.

Nem sempre isso ocorre. É o que se buscará analisar na sequência.

\section{O JUIZ, A COGNIÇÃO E A CERTEZA}

12 SOUSA, Diegro Crevelin de. O caráter mítico da cooperação processual. Disponível em: < https://emporiododireito.com.br/leitura/abdpro-10-o-carater-mitico-da-cooperacao-processual-por-diegocrevelin-de-sousa>. Acessado em: 09/08/2020.

13 SOUSA, Diegro Crevelin de. O caráter mítico da cooperação processual. Disponível em: < https://emporiododireito.com.br/leitura/abdpro-10-o-carater-mitico-da-cooperacao-processual-por-diegocrevelin-de-sousa>. Acessado em: 09/08/2020. 
A cognição implica num ato de inteligência a partir do qual o juiz considera, analisa e valora "as questões de fato e as de direito que são deduzidas no processo e cujo resultado é o alicerce, o fundamento do judicium, do julgamento do objeto litigioso do processo"14, como ensina Kazuo Watanabe.

O referido autor na sua obra clássica a respeito do assunto diferencia a cognição a partir dos planos vertical e horizontal. Horizontalmente, a cognição é percebida a partir da sua extensão ou amplitude e é limitada pelos elementos objetivos do processo (questões processuais, condições da ação e mérito da causa). Já no plano vertical, a classificação da cognição se dá "segundo o grau de sua profundidade, em exauriente (completa) e sumária (incompleta)" 15 .

Sobre a cognição exauriente, Nelson Nery Jr., diferenciando-a da sumária, ensina que o juiz "deixa de ver a questão sob o ângulo da mera plausibilidade, para ter de, agora necessariamente, examinar a lide de forma completa, segura, diante de todos os elementos de prova que o procedimento pôde produzir" $" 16$.

E os procedimentos são estruturados para que a tomada da decisão ao final seja revestida da maior certeza possível. Isso ocorre não só a partir da ampliação do debate de teses jurídicas entre as partes, mas também - e principalmente - pela ampla possibilidade de produção de provas.

Nessa linha, a prova adquire no processo a função de "permitir o embasamento concreto das proposições formuladas, de forma a convencer o juiz de sua validade, diante da sua impugnação por outro sujeito do diálogo"17.

Humberto Theodoro Jr. faz questão de reforçar a importância da produção probatória no processo, afirmando que "não se pode, evidentemente, fazer justiça sem dominar, com segurança, o quadro fático trazido à consideração do órgão judicante"18.

\footnotetext{
${ }^{14}$ WATANABE, Kazuo. Da cognição no Processo Civil. $2^{\text {a }}$ ed. atual. Campinas: Bookseller, 2000, p. 59.

${ }^{15}$ WATANABE, Kazuo. Da cognição no Processo Civil. $2^{\mathrm{a}}$ ed. atual. Campinas: Bookseller, 2000, p. 112.

${ }^{16}$ NERY JR., Nelson. Embargos infringentes: voto médio. In: 239-256. São Paulo: Editora Revista dos Tribunais, 2014, p. 246. . Soluções Práticas de Direito, vol. 10, p.

${ }^{17}$ MARINONI, Luiz Guilherme; ARENHART, Sérgio Cruz. Prova e convicção: de acordo com o CPC de 2015. $3^{\text {a }}$ ed. rev. atual. e ampl. São Paulo: Editora Revista dos Tribunais, 2015, p. 65.

${ }^{18}$ THEODORO JR., Humberto. Prova - princípio da verdade real - poderes do juiz - ônus da prova e sua eventual inversão - provas ilícitas - prova e coisa julgada nas ações relativas à paternidade (DNA). Revista de Direito Privado, vol. 17/2004, p. 9-28, Jan-Mar/2004, p. 9.
} 
Para que o quadro fático possa ser analisado com um grau maior de certeza pelo órgão julgador, o grau de exigência na produção das provas deve ser alto, pois "a exata reconstituição dos fatos é um pressuposto fundamental de decisões justas e da própria eficácia da tutela jurisdicional dos direitos" ${ }^{\prime 19}$.

Ao ressaltar a importância da investigação sobre aquilo que as provas representam no raciocínio de tomada de decisão do juiz, Michele Taruffo $^{20}$, embora reconheça a impossibilidade de se obter verdades absolutas, destaca o que chama de verdade processual, como algo ao alcance de quem atua no processo judicial. Esta verdade é que formará o convencimento do juiz, retirando-o da zona de dúvida em que se encontrava anteriormente.

De forma diversa, Marinoni e Arenhart defendem que a prova não serve para reconstruir a verdade, mas, sim, para "apoiar a argumentação retórica das partes (e também do magistrado) sobre a controvérsia exposta" ${ }^{21}$. Mas mesmo aqui, assim como os demais autores citados acima, as observações sobre a prova e a decisão judicial partem da premissa de que a dúvida foi afastada, que já há certeza sobre o que se discute.

E a certeza não equivale à verdade, frise-se. O juiz pode restar convencido por ter a certeza a partir das provas produzidas que apoiem a sua argumentação retórica a respeito da controvérsia, sem que isso signifique, necessariamente, que aquilo que restou provado seja verdadeiro.

Neste artigo, entretanto, não se adentrará nessa discussão. A exposição dos autores acima serve para demonstrar que o raciocínio desenvolvido pode variar no tocante à compreensão sobre função da prova no processo (se é a descoberta da verdade real, da verdade processual ou para apoiar a argumentação retórica das partes e do juiz), mas não varia na abordagem relativa às certezas que as provas devem gerar para possibilitar a tomada de decisão.

O ponto central é: a dúvida no momento do julgamento é pouco explorada. Parte-se do pressuposto de que, finda a atividade instrutória, o juiz, em regra, terá certezas formadas e, com isso, esconde-se um problema que eventualmente há.

\footnotetext{
${ }^{19}$ GRECO, Leonardo. A verdade no estado democrático de direito. Revista do Instituto dos Advogados de São Paulo, vol. 15/2005, p. 340-346, Jan-Jun/2005, p. 341.

${ }^{20}$ TARUFFO, Michele. Il concetto di "prova" nel Diritto Processuale. Revista de Processo, vol. 229/2014, p. 75-87, Mar/2014, p. 81.

${ }^{21}$ MARINONI, Luiz Guilherme; ARENHART, Sérgio Cruz. Prova e convicção: de acordo com o CPC de 2015. $3^{\mathrm{a}}$ ed. rev. atual. e ampl. São Paulo: Editora Revista dos Tribunais, 2015, p. 66-67.
} 


\section{A DÚVIDA E A DECISÃO}

Nem sempre, após a instrução processual, o juiz terá certezas sobre os fatos discutidos no processo. E nem sempre será possível a produção de (mais) provas, seja por uma impossibilidade material (não há provas mais), seja por uma impossibilidade formal (as provas não foram requeridas pelas partes e não tem o juiz conhecimento a respeito de quais provas poderia determinar de ofício).

A dúvida, aliás, é fator intrínseco ao processo judicial e à construção de decisões, e, como tal, deve ser naturalizada.

Do ponto de vista fático-probatório, o processo é um meio imperfeito de reprodução da realidade. A mais perfeita das evidências pode ocultar nuanças que, uma vez desveladas, teriam o potencial mesmo de alterar o resultado do julgado; que se dizer, então, de decisões que precisam se calcar exclusivamente em testemunhos, sempre à mercê da dimensão imperfeita do humano e sua memória?

Tal insuficiência é admitida e considerada pelo próprio ordenamento jurídico. O sistema recursal, com todos seus instrumentos e instâncias, nada mais é do que um mecanismo de depuração da decisão, que, longe do ideal de permitir que a jurisdição alcance intangível conceito de justiça material, visa antes prevenir danos, permitindo se obtenha um resultado ótimo de justiça possível com os elementos disponíveis.

Vai-se mais além: mesmo esse processo de depuração tem a sua insuficiência atestada pela legislação, que prevê diversos mecanismos de alteração de decisões já transitadas em julgado (ação rescisória, por exemplo).

As regras sobre distribuição do ônus da prova também consubstanciam formas de se lidar com a ausência de certeza ao julgar. Tome-se, como exemplo, demanda consumerista em que o autor afirme jamais ter celebrado contrato que justifique determinada cobrança. Sendo plausíveis suas alegações, caberá à fornecedora, mercê do disposto no artigo $6^{\circ}$, VIII, do CDC, apresentar em Juízo o contrato que justifica a exação.

Pois bem. Imagine-se que a suposta credora, embora defenda, em contestação, a existência da avença, não produza a prova documental correspondente. Essa inação pode ter ocorrido por uma variável enorme de razões, desde a efetiva inexistência do contrato até o 
fato de ele não ter sido encontrado no prazo de contestação (não é incomum, em processos desta natureza, que o instrumento contratual venha a ser juntado já em sede de recurso).

Neste caso, o juiz não terá certeza sobre a existência da contratação, e julgará com base na dúvida que, por uma construção processual, desfavorecerá aquele que poderia produzir a prova e não o fez. A dúvida, note-se, é o aspecto mais importante da fundamentação desta hipotética sentença.

Já sob uma acepção mais teórica, de aplicação do Direito aos fatos já estabelecidos como premissas de julgamento, também é possível identificar-se a dúvida como um elemento inafastável do processo decisório.

Em abono a tal proposição, a multiplicidade de teses jurídicas que se empilham sobre temas os mais diversos, desde aqueles mais prosaicos (contagem de prazo em dias úteis ou corridos no rito sumaríssimo) até os mais intrincados (aborto de fetos anencefálicos, demarcação de reservas indígenas, pesquisas com células-tronco), sendo tanto menos provável, quanto maior a complexidade da questão, que o juiz, por mais profícuos sejam seus estudos e meditações, alcance um decidir absolutamente despido de questionamentos internos. Há questões que demandam um tempo de vida para serem elaboradas, desumano exigir-se convicção plena no elastério reduzido de um processo.

Também nesta dimensão de aplicação do Direito, o sistema recursal, com mecanismos de uniformização de decisões (súmulas vinculantes, teses definidas em rito de recursos repetitivos), admite e reconhece a dúvida, agindo com o desiderato de atenuar um de seus principais efeitos: a prolação de decisões conflitantes para questões análogas.

A dúvida, portanto, consubstancia elemento indissociável à tarefa de decidir conflitos humanos por meio da prestação jurisdicional.

O não estabelecimento da certeza, no entanto, não poderá impedir a tomada de decisão, pois, uma vez chegado o momento da sentença, ao juiz não é lícito deixar de decidir. Poderá ele, inclusive, se for o caso, aplicar as regras de distribuição do ônus da prova.

O ponto é: sempre que o juiz tiver que decidir e as provas constantes dos autos não forem capazes de fazê-lo chegar no nível da certeza sobre os fatos controvertidos, a dúvida deverá ser exposta na decisão judicial. 
É preciso desmistificar o papel da dúvida na decisão e retirar dos ombros do juiz o peso de ter sempre que mostrar certeza sobre os fatos que está julgando. A exposição da dúvida na decisão não pode significar que o juiz seja incapaz de decidir, ao contrário.

Não sendo mais possível produzir provas e restando a dúvida, expô-la garantirá: a) uma decisão honesta a respeito do caso, já que o juiz não maquiará o seu estado mental de incerteza com afirmações vagas na sentença; b) a possibilidade de outro magistrado, em grau de recurso, a partir da dúvida exposta, reinterpretar as afirmações de fato e as provas e encontrar um outro caminho argumentativo, demonstrando eventual equívoco do decisor antecedente; c) a possibilidade de controle mais efetivo pelas partes do raciocínio feito pelo juiz no momento da decisão.

A fim de esclarecer essas três consequências, cada uma delas será analisada de forma mais detida a seguir.

\subsection{A dúvida e as afirmações categóricas}

O processo judicial é um ambiente de conflito de versões. É natural que o autor faça afirmações categóricas a respeito das suas alegações de fato (tese). Da mesma forma o réu também se vale de afirmativas categóricas para tentar convencer o juiz do desacerto da pretensão do autor (antítese). Cabe ao juiz a síntese do caso, nessa dinâmica dialógica do processo em contraditório.

Espera-se que as alegações fáticas sejam confirmadas pelas provas e que, associadas às teses jurídicas levantadas, gerem certezas no magistrado. Desse modo, o juiz ao decidir produzirá um pronunciamento sobre toda a discussão e toda a construção que lhe antecedeu.

Assim como as partes ofereceram afirmações categóricas, o juiz na fundamentação da sua decisão responderá às questões levantadas também de forma categórica, convencido que está sobre os fatos e sobre a tese jurídica que prevaleceu.

Este mundo ideal é rompido quando há a dúvida, mesmo depois de toda a discussão e toda a produção probatória e o juiz se vê tentado, para validar a sua tese decisória, a lançar mão de afirmações categóricas, ainda que o seu estado mental não seja de certeza.

Embora seja da praxe jurídica o redigir da decisão em termos absolutos, como se o espírito do julgador jamais houvesse de ser assaltado por qualquer hesitação, é de se 
argumentar que, diversamente do que ocorre com as partes, o juiz não tem obrigação de convencer, mas tão-somente de expor, para conhecimento e crítica, o fio lógico de seu raciocínio.

A dúvida, portanto, não deveria ser um fator estranho ou indesejável na decisão, encontrando nela, isto sim, excelente porto de atraque, por compatível com os deveres de imparcialidade e equidistância do julgador, interessado apenas em proferir a decisão mais adequada para aquele caso.

O magistrado, ao negar a dúvida, deixando de mencioná-la como fator importante no processo decisório, sonega às partes o direito de conhecer o caminho percorrido para resolvêla, interditando, em última análise, a dialética processual que conduz a uma construção democrática do decidir. Beneficia, com o peso simbólico de um palavreado definitivo, a parte que acabou por ser favorecida pela sentença.

Isso implica em uma desonestidade intelectual do juiz, que se vê compelido por aquele ambiente conflituoso e pela necessidade de exercer com efetividade a sua autoridade de dizer o direito no caso concreto, a maquiar o seu estado mental e não expor na fundamentação da decisão o que de fato resultou do seu processo interpretativo.

Admitir a dúvida é ato de desprendimento, que, ao tempo em que aproxima o juiz das partes, também o vulnerabiliza, tornando seu raciocínio mais exposto às críticas. Tal postura desafia o arquétipo já ultrapassado de juiz autoritário, que decide "de acordo com a sua consciência" sem maior preocupação em prestar contas às partes, à sociedade, à comunidade jurídica. Ora, em um processo democrático, deve importar menos a convicção íntima do juiz do que uma fundamentação que efetivamente se permita conhecer, e, portanto, fiscalizar.

Um exemplo pode esclarecer melhor este ponto: imagine-se que a parte autora tenha alegado um determinado fato e produzido provas com relação a ele, não sendo essas provas, no entanto, suficientes para a demonstração cabal daquela afirmação. Ou seja, as provas não produziram a certeza necessária para que o juiz esteja seguro a respeito da ocorrência daqueles fatos. Tem-se aí um estado de dúvida importante. Diante disso, o juiz analisará as alegações da parte contrária sobre aquele fato e verificará se houve alguma contraprova que possa tirá-lo daquele estado de dúvida. Se houver contraprova suficiente, a dúvida será 
afastada e o juiz julgará com a certeza de que o fato não se deu da forma como alegado pelo autor.

Entretanto, se também não houver contraprova, o estado de dúvida permanecerá e, por força das regras que definem a distribuição do ônus da prova, o juiz terá que decidir no sentido de que o fato não restou provado. Essa afirmação é categórica e não condiz com a realidade do exemplo descrito acima. O ideal é o juiz reconhecer que, tecnicamente, o fato não restou provado, porque a atuação da parte não foi suficiente para gerar certeza no seu convencimento, mas é de extrema importância que ele explicite que esteve em dúvida sobre a ocorrência do fato, ou seja, que ficou mais próximo da certeza do que faz crer a simples afirmação de que o fato não foi provado.

Já a alternativa nada tem de laudatória. Reprimindo a dúvida, pretendendo-a inexistente, escondendo-a sob os termos categóricos da decisão, o juiz, ainda que de forma não deliberada, passa a ser um defensor de sua própria sentença, um refém dos termos imperativos adotados na fundamentação, afastando-se dos deveres de honestidade intelectual e mesmo de imparcialidade que se exigem de um ator processual desinteressado.

Trata-se de um passo perigoso.

Em primeiro lugar, porque o compromisso do magistrado passa a ser com sua própria autoridade, e não com a transparência do processo decisório. Tal encastelamento impede, a título de exemplo, que eventuais lacunas interpretativas venham a ser colmatadas por meio dos embargos de declaração. Em lugar de um esforço honesto para se atingir a decisão mais adequada possível - processo em que deveria ser natural a o esclarecer e mesmo o voltar atrás, com atribuição de efeitos infringentes ao próprio julgado (artigo 1.024, § $4^{\circ}$, do CPC) - teremos a figura do juiz que se desdobra para defender a correção de seu próprio ato decisório, em postura defensiva e fechada a objeções pertinentes.

Daí dizer que a adoção de termos categóricos para pontos em que, na verdade, há incertezas, fecha o debate, interdita a comunicação entre o juiz e as partes, impede que o magistrado se deixe influenciar por contra-argumentos plausíveis. O magistrado afasta-se da lógica de coparticipação, em que atua horizontalmente, em cooperação com as partes, no construir de uma decisão adequada, para aceder ao arquétipo autoritário de detentor da última palavra, agindo em uma lógica de hierarquia vertical incompatível com um processo democrático. 
Em segundo, porque a dúvida vai existir, se não sempre, muitas vezes. E tudo aquilo que, suposto exista, venha a ser recalcado, acaba por se exteriorizar de forma inconsciente, alheia ao controle da racionalidade que deve permear o processo decisório.

Em outras palavras, os esforços envidados pelo juiz para dissimular sua própria incerteza podem ensejar, de outro lado, uma super-compensação (de que a adoção de linguagem superlativa é indício), muitas vezes capaz de influir em aspectos relevantes da decisão. $\mathrm{O}$ alto valor de uma indenização por danos morais, por exemplo, pode ser inversamente proporcional ao grau de convicção sobre a ocorrência do ato ilícito que lhe deu ensejo.

O tom de certeza, onde deveria haver declaração expressa da dúvida existente, passa a funcionar como um anteparo, um mecanismo de defesa, a isolar o juiz do necessário diálogo cooperativo com as partes, imprescindível à construção horizontal e coparticipativa de uma decisão adequada.

De outro lado, a simples abordagem da incerteza tem o poder de neutralizá-la, permitindo que o juiz ingresse no círculo hermenêutico em um maior grau de honestidade intelectual, que certamente refletirá na qualidade da fundamentação.

Esse reconhecimento da dúvida pelo juiz, longe de demonstrar a sua fragilidade, apenas reforça o caráter democrático do processo e fortalece a própria decisão judicial, que representará efetivamente a exposição do processo interpretativo do juiz a respeito daquele caso concreto.

\subsection{A reinterpretação a partir da dúvida}

Notadamente no recurso de apelação, o tribunal fará a reinterpretação dos fatos que foram objeto da sentença oferecida pelo juízo de primeira instância, e este é inclusive um dos argumentos de quem defende não se poder mais falar que o destinatário da prova é o juiz, referindo-se ao magistrado de primeiro grau. Além das partes, também outros magistrados que participarão da cadeia decisória no processo são destinatários da prova.

É natural que as provas sejam reinterpretadas em grau recursal e isso ocorrerá a partir daquilo que constar da sentença. O tribunal, no julgamento do recurso, não parte de um grau 
zero de sentido, até mesmo por conta do efeito devolutivo do recurso. Então, o ponto de partida para o seu julgamento será exatamente a decisão recorrida.

Parte-se da sentença, consideradas as razões e as contrarrazões recursais, para a reanálise dos fatos e das provas produzidas ao longo da instrução processual. E como ponto de partida a sentença tem grande influência sobre a formação do convencimento dos

julgadores. E deve ser assim mesmo. É importante que o juiz que teve contato imediato com a produção probatória seja "ouvido" pelo tribunal quando do julgamento do recurso, sob pena de a primeira instância ser um mero rito de passagem.

E tão melhor será a influência da decisão proferida pelo julgador em primeiro grau quanto mais honesta for a sua fundamentação.

Em linha de princípio, ao juiz não cabe convencer as partes a respeito do acerto da sua decisão e nem mesmo convencer aos demais julgadores do futuro. A sua função primordial é a de decidir adequadamente o caso, sem pretensões de educar a sociedade, as partes ou quem quer que seja. E essa decisão adequada significa que os limites impostos pelo ordenamento foram obedecidos pelo magistrado.

Vale dizer, o juiz decidiu respeitando o comando do devido processo legal e tudo o que dele decorre (contraditório, ampla defesa, imparcialidade, fundamentação das decisões etc.), a partir das provas produzidas, dentro dos limites da demanda estabelecidos pelo autor e chegou a uma conclusão. Se esta conclusão não é fruto de uma certeza, a dúvida há de ser exposta, tal como ela se apresenta, porque na reinterpretação do caso é possível que os outros julgadores compreendam a dúvida do juiz anterior e a reafirmem ou mesmo que a afastem, por entenderem que houve um equívoco interpretativo do magistrado sobre as provas produzidas.

A abordagem, em fundamentação, de todo o raciocínio engendrado pelo magistrado para resolver, com aplicação do ordenamento vigente, as questões submetidas a sua apreciação, aí incluídas as dúvidas e a forma pela qual foram resolvidas, é o primeiro passo essencial para o amadurecimento da solução atribuída à lide, em uma perspectiva interna, nos limites do processo e suas instâncias recursais, bem como para que a tese jurídica firmada, em uma acepção externa, possa se inscrever em um processo de amadurecimento jurisprudencial. 
O silogismo que dá forma a uma sentença, enfim, deve ser testado sob um semnúmero de variantes, perspectivas e argumentos, tanto provindos das partes, internamente, como da comunidade jurídica, externamente, podendo, neste processo democrático, ser confirmado, refutado, agregado com outros elementos, extrapolado a casos análogos, ou simplesmente abandonado.

Para este amadurecimento, é necessário que as razões e dúvidas que envolveram aquele processo decisório sejam dados a conhecer: eis a obrigação primordial de um juiz no âmbito de um processo democrático.

\subsection{O controle pelas partes}

Somada a isso, a exposição honesta da dúvida permitirá um controle mais efetivo da decisão judicial por eventuais instâncias superiores, em grau recursal. Embora a decisão judicial não se preste a convencer as partes sobre o acerto da interpretação do juiz, a fundamentação serve para que seja possível um controle efetivo do que foi decidido. É isso que confere à decisão judicial o seu valor democrático: a possibilidade de controle.

Quando há dúvida e ela não é exposta na decisão, lançando o juiz mão de argumentos retóricos e afirmações categóricas para mascarar o seu real estado mental, o controle democrático da decisão resta prejudicado.

Se do processo interpretativo do juiz resultou um estado mental de dúvida, é direito da parte saber disso, para que possa insurgir-se contra a decisão e demonstrar que houve um equívoco interpretativo sobre as provas produzidas. $\mathrm{E}$ isso afeta, inclusive, a parte que foi beneficiada pela decisão.

Imagine-se o caso da ação que é julgada improcedente porque o juiz não restou convencido das alegações de fato formuladas pelo autor. Se o juiz expõe a sua dúvida, esclarecendo que chegou próximo à certeza, mas não o suficiente para entender que o autor se desincumbiu do seu ônus, ele esclarece também ao réu que a sua antítese não lhe dá a tranquilidade necessária diante de um eventual recurso de apelação.

A exposição da dúvida pelo juiz colocará o réu em estado de alerta, por saber que, embora a ação tenha sido julgada improcedente, o juiz da primeira instância chegou próximo da certeza, havendo um sincero risco de que os julgadores do recurso de apelação sejam 
efetivamente convencidos pelo autor. Com isso, o réu terá, inclusive, interesse recursal, ainda que a sucumbência não o tenha atingido, pois ele poderá buscar, em recurso de apelação que haja o reconhecimento da improcedência da demanda inicial, mas não mais baseada na dúvida e, sim, na certeza de que a tese do autor não merece acolhida.

E nesse ponto, importa destacar, há necessidade de se pensar o interesse recursal daquela parte que, embora vencedora, teve o julgado baseado em quase certeza. Diante do risco de uma interpretação diferente sobre aqueles fatos e provas pelo tribunal em segunda instância, é plenamente justificável a insurgência recursal da parte, para buscar retirar do julgado a dúvida.

Isso seria crucial, principalmente, se considerada a fase recursal seguinte, perante os tribunais superiores, que vão partir do enquadramento jurídico e fático feito no julgamento da segunda instância.

Dessa forma, a sucumbência a justificar a interposição de um recurso nessas circunstâncias diria respeito não somente ao resultado quanto ao pedido, mas também à forma como se deu a construção do fundamento de fato a justificar a decisão. Se há uma dúvida exposta pelo magistrado, ainda que ela tenha beneficiado uma das partes, vencedora quanto ao pedido, há uma espécie de sucumbência quanto ao argumento e a parte pode desejar solidificá-lo na próxima fase, de natureza recursal, de modo a perseguir uma maior segurança jurídica quanto à resposta dada pelo Judiciário àquele conflito de interesses.

Ao processo democrático, importa garantir, objetivamente, controle e fiscalização sobre a fundamentação das decisões judiciais.

Assim sendo, pouco importa, que, ao prolatar a decisão, o juiz tenha, em seu íntimo, absoluta convicção da solução alcançada, desde que tenha externado, da forma mais transparente possível, quais foram os caminhos lógicos percorridos para saná-la, e por que a solução adotada tenha sido a mais razoável e consentânea com o ordenamento, permitindo que os fundamentos adotados sejam objeto de amplo escrutínio pelas partes. Neste contexto, sonegar a dúvida, quando existente, assemelha-se a sonegar fundamentação.

E é o controle pelas partes, enfim, a principal finalidade da exposição da dúvida pelo juiz. Se o processo é ambiente de diálogo, com as partes debatendo entre si e o juiz tendo o dever de responder adequadamente às questões que lhe são postas, e se há dever de boa-fé 
que incide inclusive sobre o juiz, é possível afirmar que as partes têm o direito de saber quando o juiz decidiu em dúvida, e quais critérios utilizou para saná-la.

De resto, ao franquear, aos litigantes, acesso a todos os meandros de seu processo decisório, incluídas hesitações e dúvidas, o juiz acaba por demonstrar que efetivamente engendrou um esforço genuíno para conferir a melhor solução possível àquele caso. A parte terá sido ouvida, e não invisibilizada; seu problema, considerado honestamente, e não repelido em meio a jargões e brocardos a ela ininteligíveis. Esse reconhecimento das partes como sujeitos de direito, destinatários legítimos de um dever de fundamentação por parte do magistrado, afigura-se inclusive como fator importante de pacificação do conflito, qualquer tenha sido o resultado da demanda.

A construção democrática, coparticipativa e horizontal de uma resposta jurisdicional adequada, suscetível ao controle das partes e da comunidade jurídica, enfim, passa pela necessidade de uma fundamentação que exprima todos os aspectos relevantes no processo de tomada de decisão, as dúvidas, inclusive.

\section{CONSIDERAÇÕES FINAIS}

Feitas essas considerações, conclui-se que: a) nem sempre, ao fim da instrução processual, o juiz terá certezas a respeito conflito estabelecido, pois embora as provas destinem-se à produção da certeza no convencimento do juiz, há situações em que isso é impossível, formal ou substancialmente; b) é inadequado quando o juiz, estando em dúvida, faz afirmações categóricas na sua decisão, para mascarar o seu estado mental; c) é antidemocrática a decisão proferida nesses termos; d) é preciso desmistificar o papel da dúvida na decisão judicial, pois a sua exposição não pode significar a fragilidade do juiz e do produto do seu trabalho no processo; e) a exposição da dúvida pelo juiz permite uma decisão honesta a respeito do caso, já que o juiz não maquiará o seu estado mental de incerteza com afirmações vagas na sentença; f) a exposição da dúvida pelo juiz possibilita que outro magistrado, em grau de recurso, a partir da dúvida exposta, reinterprete as afirmações de fato e as provas e encontre um outro caminho argumentativo, demonstrando eventual equívoco do decisor antecedente; g) a exposição da dúvida pelo juiz permite um controle mais efetivo pelas partes do raciocínio feito pelo juiz no momento da decisão; h) há 
um direito das partes à fundamentação das decisões judiciais, que implica no direito à explicitação da dúvida, quando ela houver, e este direito decorre também do contraditório e da boa-fé processual.

\section{REFERÊECIAS:}

COSTA, Eduardo José da Fonseca. Processo: garantia de liberdade (freedom) e garantia de "liberdade" (liberty). Disponível em: <https://emporiododireito.com.br/leitura/processo-garantia-de-liberdade-freedom-egarantia-de-liberdade-liberty>. Acessado em 09/08/2020.

DIDIER JR., Fredie. Curso de Direito Processual Civil: introdução ao Direito Processual Civil, parte geral e processo de conhecimento. $17^{\mathrm{a}}$ ed. rev. ampl. e atual. Salvador: JusPodivm, 2015.

GRECO, Leonardo. A verdade no estado democrático de direito. Revista do Instituto dos Advogados de São Paulo, vol. 15/2005, p. 340-346, Jan-Jun/2005.

LEAL, Rosemiro Pereira. Teoria geral do Processo: primeiros estudos. $14^{\mathrm{a}}$ ed. rev. ampl. e atual. Belo Horizonte: Fórum, 2018.

MARINONI, Luiz Guilherme, MITIDIERO, Daniel. Código de Processo Civil comentado artigo por artigo. São Paulo: RT, 2008.

MARINONI, Luiz Guilherme; ARENHART, Sérgio Cruz. Prova e convicção: de acordo com o CPC de 2015. $3^{\text {a }}$ ed. rev. atual. e ampl. São Paulo: Editora Revista dos Tribunais, 2015 .

MITIDIERO, Daniel. Colaboração no Processo Civil: pressupostos sociais, lógicos e éticos. $2^{\mathrm{a}}$ ed. rev. atual. e ampl. São Paulo: Editora Revista dos Tribunais, 2011.

NERY JR., Nelson. Embargos infringentes: voto médio. In: Soluções Práticas de Direito, vol. 10, p. 239-256. São Paulo: Editora Revista dos Tribunais, 2014.

SOUSA, Diego Crevelin de. O caráter mítico da cooperação processual. Disponível em: < https://emporiododireito.com.br/leitura/abdpro-10-o-carater-mitico-da-cooperacaoprocessual-por-diego-crevelin-de-sousa>. Acessado em: 09/08/2020.

TARUFFO, Michele. Il concetto di "prova" nel Diritto Processuale. Revista de Processo, vol. 229/2014, p. 75-87, Mar/2014. 
Rio de Janeiro. Ano 16. Volume 23. Número 1. Janeiro a Abril de 2022

Periódico Quadrimestral da Pós-Graduação Stricto Sensu em Direito Processual da UERJ

Patrono: José Carlos Barbosa Moreira (in mem.). ISSN 1982-7636. pp. 1296-1318 www.redp.uerj.br

THEODORO JR., Humberto e outros. Novo CPC: fundamentos e sistematização. Rio de Janeiro: Forense, 2015.

THEODORO JR., Humberto. Prova - princípio da verdade real - poderes do juiz - ônus da prova e sua eventual inversão - provas ilícitas - prova e coisa julgada nas ações relativas à paternidade (DNA). Revista de Direito Privado, vol. 17/2004, p. 9-28, JanMar/2004.

WATANABE, Kazuo. Da cognição no Processo Civil. $2^{\mathrm{a}}$ ed. atual. Campinas: Bookseller, 2000 . 